\title{
Michał Kuśmirski
}

Katolicki Uniwersytet Lubelski Jana Pawła II, Polska

michal.kusmirski2@gmail.com

ORCID: 0000-0002-1113-1706

\section{Charakter prawny danin publicznych w polskim prawie podatkowym}

\begin{abstract}
ABSTRAKT
W artykule poruszono kwestię charakteru prawnego danin publicznych pod względem klasyfikacji ich na polu formalno-materialnym. Skupiono się na podatkach i opłatach jako dwóch głównych przedstawicielach tej grupy świadczeń publicznych. Celem opracowania było ukazanie rzeczywistego charakteru niektórych danin publicznych w polskim prawie podatkowym. W związku z tym omówiono ten zbiór świadczeń publicznych, a następnie oddzielnie przedstawiono podatek i opłatę, ukazując ich znaczenie, cechy wspólne oraz różnice. Prawidłowe wyróżnienie odpłatności i jej braku pozwoliło dokonać właściwej analizy i klasyfikacji danin publicznych, omówić problem błędnego nazewnictwa tych świadczeń, a także stwierdzić, które z opłat są w rzeczywistości opłatami, a które mają raczej cechy podatku. Ze względu na badanie obowiązujących przepisów prawa podatkowego w niniejszym tekście posłużono się metodą dogmatyczną. Dodatkowo posiłkowano się metodą socjologiczną i historyczną.
\end{abstract}

SŁOWA KLUCZOWE

daniny publiczne, podatek, opłata, odpłatność

\section{Legal nature of public tributes in Polish law}

\section{ABSTRACT}

The issue of the legal nature of the public tributes in terms of classifying them in the respect of formalsubstantive territory was raised in the article. The focus was put on taxes and fees as two main representatives of this public services group. The purpose of this study was to show the real character of some public tributes in the polish tax law. Thereupon this group of public services was discussed and then the tax and fee were addressed separately. Thanks to that their meaning, common features and differences were indicated. The valid indication of remuneration and its absence made the correct analysis and classification of the public tribute possible, it also allowed to address the issue of the incorrect nomenclature of these services and to indicate which of these are in fact fees and which them are more of a tax. Due to the research of the effective regulations of the tax law, in this study the dogmatic method was applied. In addition to that, the sociological and historical methods were also used. 
KEYWORDS

public tributes, tax, fee, remuneration

\section{Wstęp}

Każdy ma obowiązek ponoszenia ciężarów i świadczeń publicznych ${ }^{1}$, do których niewątpliwie kwalifikują się daniny publiczne. Porządek ten wynika bezpośrednio z ustawy zasadniczej ${ }^{2}$. Wskazane w niej przepisy są również źródłem kompetencji władzy ustawodawczej do nakładania na obywateli obciążeń finansowych ${ }^{3}$. Z perspektywy części podatników, niebędących profesjonalnymi uczestnikami obrotu gospodarczego, są to informacje wyczerpujące, gdyż istotną dla nich kwestią jest samo istnienie obowiązku zapłaty daniny publicznej oraz jej wysokość. Spełnienie tej powinności może wynikać z obowiązku obywatelskiego albo z obawy przed sankcjami władzy publicznej ${ }^{4}$. W każdej sytuacji będzie to jedynie czynność, którą trzeba wykonać pod przymusem. Dlatego też dla podatnika nie jest kluczowe, jaką daninę publiczną w rzeczywistości uiszcza. W związku z tym nie zna ich rozróżnienia i płynących $\mathrm{z}$ tego konsekwencji. Ma to przełożenie na aktualnie stosowaną nomenklaturę w życiu publicznym, gdzie takie pojęcia jak podatek i opłata używane są coraz częściej zamiennie. Bez wątpienia są to oddzielne kategorie. W czasach coraz głośniejszych postulatów o potrzebie wprowadzenia prostych i niskich podatków utworzenie nowej opłaty nie kojarzy się tak pejoratywnie. Zatem odmienne określanie danin publicznych może być korzystne wizerunkowo $\mathrm{z}$ perspektywy suwerena ${ }^{5}$.

Z punktu widzenia systematyki prawa finansowego każda danina publiczna ma swoje własne cechy. W związku z tym podatek, opłata czy też składka to pojęcia niejednakowe, określające różne rodzaje świadczeń publicznych. Nazewnictwo zastosowane przez ustawodawcę w stosunku do konkretnej daniny publicznej nie determinuje zakwalifikowania jej do innego świadczenia, niż wynika to z analizy jej cech. Jest to kluczowe w kontekście jej rozróżnienia. W związku z tym opłaty skarbowej nie można nazwać podatkiem, a podatku dochodowego od osób fizycznych opłatą i to nawet, jeżeli normatywnie określona zostałaby jako „opłata od osób fizycznych”. W następstwie tego nasuwają się pytania o prawidłowe rozróżnienia tych pojęć. Dlaczego są one błędnie systematyzowane zarówno w opinii pu-

1 Konstytucja Rzeczypospolitej Polskiej z dnia 2 kwietnia 1997 r., Dz.U. 1997 nr 78 poz. 483 z późn. zm. (dalej: krp), art. 84 .

2 Florczak-Wątor, M., Obowiązek ponoszenia ciężarów i świadczeń publicznych, w Tuleja, P. (red.), Konstytucja Rzeczypospolitej Polskiej. Komentarz. Warszawa 2019, s. 272-275.

3 Art. $217 \mathrm{krp}$.

4 Niesiobędzka, M., Relacje podatnik-państwo jako predyktory moralności podatkowej, Psychologia Społeczna 2009, t. 4, s. 123-124.

5 Dowgier, R. et al., Podatki i opłaty lokalne. Komentarz. Warszawa 2020, s. 21-25.

6 Krzywoń, A., Podatki i inne daniny publiczne - podstawowe pojęcia konstytucyjne, Zeszyty Naukowe Sądownictwa Administracyjnego 2011, nr 2, s. 48-55. 
blicznej, jak i przez ustawodawcę? Jak kształtuje się wobec tego klasyfikacja polskich danin publicznych? Czy dla podmiotu biernego ma znaczenie, jakiego rodzaju powinność jest zobowiązany spełnić? W dalszej części podjęto próbę rozwiązania tych problemów. Poprzez porównanie rodzajów danin publicznych wskazano ich różnicę oraz dokonano oceny kwalifikacji polskich świadczeń publicznoprawnych. Skupiono się głównie na podatku i opłacie jako najczęściej mylonych pojęciach.

\section{Charakterystyka i znaczenie danin publicznych}

Wraz z ewolucją człowieka i początkiem państwowości pojawiła się potrzeba odejścia od gospodarki naturalnej. Coraz bardziej rozbudowane struktury administracyjne wymagały przejścia do obowiązkowych świadczeń pieniężnych. $Z$ biegiem czasu doraźnie nakładane na obywateli obciążenia zastąpione zostały w przeważającej większości przez stałe obciążenia podatkowe ${ }^{7}$. Skutkiem tego procesu było powstanie danin publicznych. Pojęcie to pomimo swojego wieku nie zostało w polskim systemie prawnym precyzyjnie zdefiniowane.

Klasyfikacja konkretnego świadczenia następuje na podstawie kryterium celu jego ustanowienia przez ustawodawcę oraz analizy jego cech materialnych. Daniny publiczne, zaliczane do sektora dochodów publicznych, mają bezzwrotny i prognostyczny charakter. Są świadczeniem pieniężnym ustanowionym, pobieranym oraz gromadzonym przez organy władzy publicznej. Bezzwrotność oznacza, że jest ono ostateczne, nie podlega też zwrotowi, jeżeli pobrane zostało zgodnie z prawem. Prognostyczny charakter wiąże się z odgórnym określaniem wysokości danin publicznych w budżetach państwa i jednostek samorządów terytorialnych, a także planach finansowych jednostek budżetowych ${ }^{8}$. Spełnienie tego świadczenia $\mathrm{w}$ formie pieniężnej jest konsekwencją pieniężnej formy gospodarki finansowej jako całości'. Należy zauważyć, że wszystkie daniny publiczne stanowią dochód budżetu państwa i powinny być bezzwrotne, powszechne i przymusowe ${ }^{10}$.

Daniny publiczne są głównym źródłem dochodów publicznych ${ }^{11}$. Mimo to ustawodawca zdecydował się dokonać ich wyliczenia, zamiast zdefiniowania ${ }^{12}$, i włączył do nich: podatki, składki, opłaty, wpłaty z zysku przedsiębiorstw państwowych i jednoosobowych spółek Skarbu Państwa oraz banków państwowych, jak również inne świadczenia pieniężne, których obowiązek ponoszenia na rzecz państwa, jednostek samorządu terytorialnego, państwowych funduszy celowych, a także innych jednostek sektora finansów publicznych wy-

7 Mirek, I., Daniny publiczne w prawie niemieckim. Warszawa 1999, s. 25.

8 Ustawa z dnia 27 sierpnia 2009 r. o finansach publicznych, tekst jedn. Dz.U. z 2019 poz. 869 z późn. zm. (dalej: fp), art. 52.

9 Gliniecka, J., Opłaty publiczne w Polsce. Analiza prawna i funkcjonalna. Bydgoszcz-Gdańsk 2007, s. 12-13.

10 Wyrok NSA z 22 listopada 2019 r., II GSK 991/19, LEX nr 2764702.

11 Dębowska-Romanowska, T., Prawo daninowe - podstawowe pojęcia konstytucyjne i ustawowe cz. I, Glosa 1996, nr 11, s. 3.

12 Bożek, W., Znaczenie danin publicznych $w$ budżecie państwa, w Mańczyk, P. (red.), Daniny publiczne w Polsce i innych państwach Europy. Szczecin 2018, s. 58-62. 
nika $z$ odrębnych ustaw ${ }^{13}$. Chociaż podatek doczekał się swojej definicji legalnej ${ }^{14}$, próżno szukać jej przy pozostałych daninach publicznych. W celu umiejscowienia ich w strukturze finansów publicznych należy wskazać, że razem z innymi dochodami o bardzo zróżnicowanym charakterze są one częścią dochodów publicznych. Te zaś obok przychodów publicznych i środków pochodzących ze źródeł zagranicznych, które nie podlegają zwrotowi, tworzą grupę środków publicznych ${ }^{15}$.

Daniny publiczne w przeważającej mierze stanowią o wielkości środków, jakimi dysponują organy publiczne. Wśród nich niewspółmiernie największy udział mają dochody podatkowe, które w latach 2013-2017 wynosiły od 85\% do 90\% dochodów budżetu państwa w Polsce ${ }^{16}$, już natomiast w okresie 2018-2019 ich udział osiągał niemal $92 \%{ }^{17}$. Klasyfikuje to daniny publiczne pośród najważniejszych czynników determinujących politykę finansową państwa.

\section{Podatek jako najważniejszy instrument polityki fiskalnej państwa}

Podatek jest to publicznoprawne, nieodpłatne, przymusowe oraz bezzwrotne świadczenie pieniężne na rzecz Skarbu Państwa, województwa, powiatu lub gminy, wynikające z ustawy podatkowej $^{18}$. Jego publicznoprawny charakter wywodzi się z przynależności do danin publicznych. Nakłada się go na podmioty bierne stosunku prawnopodatkowego na podstawie władztwa publicznego. Nie jest więc wynikiem umowy cywilnej między stronami, lecz stosuje się do niego przepisy prawa publicznego. Nieodpłatność podatku oznacza, że podatnik nie ma prawa do żądania świadczenia wzajemnego od państwa czy też jednostki samorządu terytorialnego. Podmiot czynny zobowiązania podatkowego nie jest obowiązany do żadnego bezpośredniego świadczenia na rzecz podatnika płacącego tę należność publicznoprawną. Przymusowy charakter tego świadczenia oznacza, że organy podatkowe dysponują instrumentami prawnymi mającymi zagwarantować zapłatę podatku. Służące ku temu środki prawne dają możliwość jego wyegzekwowania w sytuacji, kiedy podmiot bierny zobowiązania podatkowego nie chce dokonać tego dobrowolnie. Podatek zapłacony we właściwej wysokości co do zasady nie podlega zwrotowi. Cecha ta określona została jako bezzwrotność. Odróżnia to podatek od takich świadczeń jak pożyczka i kredyt, które w danej jednostce czasu powinny zostać zwrócone. Dodatkowo jest to również świadczenie

13 Art. 5 ust. 2 pkt 1 fp.

14 Ustawa z dnia 29 sierpnia 1997 r. Ordynacja podatkowa, tekst jedn. Dz.U. z 2020 poz. 1325 z późn. zm. (dalej: op), art. 6.

15 Wójtowicz, W., Podstawowe zagadnienia ustawy o finansach publicznych, w Wójtowicz, W. (red.), Zarys finansów publicznych i prawa finansowego. Warszawa 2020, s. 32-33.

16 Bożek, W., op. cit., s. 64-66.

17 Rada Ministrów, Sprawozdanie z wykonania budżetu państwa za okres od 1 stycznia do 31 grudnia 2018 r., tom I, 2019. https://www.gov.pl/web/finanse/sprawozdanie-roczne-za-2018, dostęp 12.11.2020; Rada Ministrów, Sprawozdanie z wykonania budżetu państwa za okres od 1 stycznia do 31 grudnia 2019 r., tom I, 2020. https://www.gov.pl/web/finanse/sprawozdanie-roczne-za-2019-rok, dostęp 12.11.2020 (dalej: Sprawozdanie).

18 Art. 6 op. 
pieniężne, w związku z tym wysokość podatku nie może być wskazana za pomocą innego kryterium niż pieniądz. Ostatnią wartą poruszenia cechą tego świadczenia publicznego jest spełnienie jej na rzecz określonych podmiotów. Są to Skarb Państwa oraz jednostki samorządu terytorialnego w postaci województwa, powiatu i gminy. W związku z tym podatki nie mogą stanowić dochodu innych podmiotów niż wskazanych powyżej $j^{19}$.

O znaczeniu tej daniny publicznej wśród dochodów publicznych świadczy nie tylko fakt zdefiniowania jej przez ustawodawcę, lecz także wyróżnienie jej jako osobne świadczenie w konstytucji ${ }^{20}$. Jak wskazano powyżej, podatki są również najistotniejszym dochodem budżetowym w Polsce pod względem wysokości zapewnianych wpływów. Dodatkowo jeszcze w ostatnim czasie ich udział względem innych dochodów uległ zwiększeniu. W $2019 \mathrm{r}$. dochody z podatków wyniosły 367,3 mld zł na 400,5 mld zł łącznych dochodów budżetu państwa. Oznacza to, że niespełna $92 \%$ ciężarów i świadczeń publicznych ponoszonych przez obywateli stanowiły podatki. Warto wskazać, że oprócz danin publicznych do budżetu państwa trafiły też między innymi grzywny, środki z Unii Europejskiej i innych źródeł niepodlegających zwrotowi. Wśród samych dochodów podatkowych niespełna połowa pochodziła z podatku od towarów i usług. Trzema następnymi i z perspektywy fiskalnej najistotniejszymi były kolejno podatki: akcyzowy, dochodowy od osób fizycznych oraz dochodowy od osób prawnych. Inne podatki stanowiły niewielki procent w ich ogólnym udziale $^{21}$. W rzeczywistości więc obowiązek ponoszenia ciężarów i świadczeń publicznych w przeważającej mierze sprowadza się do płacenia podatków.

\section{Opłata w polskim prawie}

W polskim systemie prawnym brakuje definicji legalnej opłaty. Jeszcze w 2017 r. próbowano zmienić ten stan poprzez unormowanie pojęcia wskazanej daniny publicznej, do tej pory jednak bezskutecznie ${ }^{22}$. Pomimo tego można dokonać klasyfikacji opłaty na podstawie charakteryzujących ją cech. Jest to danina publiczna nakładana jednostronnie, o charakterze publicznoprawnym, pieniężnym, zasadniczym, bezzwrotnym, przymusowym i ogól$n_{y m^{23}}$. Od podatku odróżnia ją jedynie kwestia odpłatności ${ }^{24}$. W związku z uiszczeniem opłaty uzyskuje się prawo do świadczenia wzajemnego, które może być ekwiwalentne lub nieekwiwalentne. Świadczeniem tym jest czynność Skarbu Państwa, jednostki samorzą-

19 Popławski M., Normatywne pojęcie podatku, w Etel, L. (red.), Ordynacja podatkowa. Komentarz. Warszawa 2017, s. $105-107$.

20 Art. 84, $217 \mathrm{krp}$.

21 Sprawozdanie.

22 Projekt ustawy - Ordynacja podatkowa z dnia 6 października 2017 r. https://mf-arch2.mf.gov.pl/ministerstwofinansow/dzialalnosc/ciala-kolegialne/komisja-kodyfikacyjna-ogolnego-prawa-podatkowego/prace-komisji, dostęp 31.03.2021.

23 Adam, L. i Mazurkiewicz, M., Opłaty, w Weralski, M. (red.), System instytucji prawno-finansowych PRL, t. 3, Wrocław 1982, s. 466-467.

24 Wyrok WSA w Poznaniu z 18 grudnia 2019 r., III SA/Po 371/19, LEX nr 2761074. 
du terytorialnego albo innego podmiotu upoważnionego na mocy ustaw podatkowych do pobierania opłat ${ }^{25}$. Z pojęciem odpłatności niewątpliwie wiąże się kwestia stopnia ekwiwalentności ${ }^{26}$. Jeżeli świadczenie administracyjne odpowiada wartości zapłaconej opłaty, wówczas występuje jej pełna ekwiwalentność. Jest to klasyczna forma opłaty, która jednak w takim przypadku może zawierać pewne cechy ceny. W sytuacji odwrotnej, kiedy opłata wynosi znacznie więcej niż wartość świadczonej usługi, nabiera właściwości podatku. W związku z tym, jeżeli wysokość opłaty jest niewspółmierna do kosztów rzeczywistych świadczonej usługi, to powinna ona być uznana za podatek ${ }^{27}$.

Dochody z tytułu opłat w budżecie państwa są znacznie mniej istotne niż dochody podatkowe. W 2019 r. cała grupa świadczeń obejmujących nie tylko tę daninę publiczną, lecz także grzywny, odsetki i inne dochody niepodatkowe, osiągnęła łączną wysokość 20,9 mld zł. Stanowiło to jedynie przeszło $0,5 \%$ wszystkich dochodów budżetu państwa ${ }^{28}$. Opłaty mają większy udział w strukturze dochodów własnych jednostek samorządu terytorialnego. Pomimo to również tutaj tworzą niewydajną grupę dochodów. Potwierdza to fakt, że w latach 1999-2007 dochody z opłat stanowiły średnio 3,3\% wszystkich dochodów własnych jednostek samorządu terytorialnego, dodatkowo z wyraźną tendencją spadkową ${ }^{29}$. Wynikająca $z$ tego dysproporcja pomiędzy obciążeniem obywatela podatkami a opłatami wskazuje na śladową ilość tych drugich w ogólnym rozrachunku. Okoliczność ta może powodować w opinii publicznej brak świadomości istnienia innych świadczeń niż podatkowe.

\section{Różnica między podatkiem a opłatą}

Jak już wcześniej wskazano, odpłatność jest cechą odróżniającą od siebie omawiane daniny publiczne. Jako że jest to jedyny czynnik umożliwiający dokonanie właściwej klasyfikacji tych świadczeń publicznych ${ }^{30}$, należy dokładnie omówić, co kryje się pod tym pojęciem. Czynność prawna jest odpłatna, jeśli podmiot dokonujący przysporzenia dostaje lub ma dostać w zamian korzyść majątkową jako ekwiwalent takiego przysporzenia. Występuje ona w momencie, kiedy strony dokonują między sobą wymiany materii posiadającej przynajmniej, co do zasady, określoną wartość oraz będącą przedmiotem obrotu. Odpłatne czynności prawne są czynnościami podwójnie zobowiązującymi, co oznacza, że każda ze stron ma prawo do danej korzyści majątkowej ${ }^{31}$.

25 Münnich, M., Charakterystyka opłaty legalizacyjnej jako daniny publicznej, Przegląd Prawa Publicznego 2015, nr 10, s. 70-77.

26 Wyrok NSA z 26 lipca 2012 r., I OSK 679/12, LEX nr 1392334.

27 Wyrok TK z 17 stycznia 2006 r., U 6/04, OTK 2006, nr 1, poz. 3.

28 Sprawozdanie.

29 Kotlińska, J., Dochody własne jednostek samorządu terytorialnego w Polsce, Ruch Prawniczy, Ekonomiczny i Socjologiczny 2009, nr 3, s. 155-156.

30 Wyrok NSA z 28 października 2008 r., II OSK 1179/07, LEX nr 1012219.

31 Węgrzynowski, Ł., Ekwiwalentność świadczeń w umowie wzajemnej. Warszawa 2011, s. 148-150. 
Opłata jest indywidualną zapłatą za skonkretyzowane świadczenie. Wskazuje to również na ekwiwalentność odpłatnego świadczenia ${ }^{32}$. Zgodnie $\mathrm{z}$ tym jego wartość powinna odpowiadać wysokości zapłaconej opłaty. Innymi słowy, wysokość opłaty pokrywa koszty związane ze świadczeniem usługi, za które została ona pobrana ${ }^{33}$. Zaburzenie tej proporcji, poprzez zbyt wysoką opłatę w stosunku do świadczenia otrzymanego w zamian, prowadzi do przybliżenia tej daniny publicznej do podatku ${ }^{34}$. Kluczowe jest więc ustalenie zakresu ekwiwalentności. Bezsprzecznie mieści się w nim sytuacja, kiedy wartość obu świadczeń jest równorzędna. Występuje wtedy pełna ekwiwalentność. W doktrynie przyjmuje się jednak również za dopuszczalne uznanie ekwiwalentności niepełnej, ale opartej na związku przyczynowo-skutkowym, łączącym opłatę publiczną oraz czynność organu publicznego. Uzasadnia to okoliczność, że ze względu na wielość form świadczeń wzajemnych za opłatę ich wartość nie zawsze da się skonkretyzować. Wskazaną wyżej korzyścią majątkową dla strony płacącej opłatę jest czynność urzędowa albo świadczenie usług jednostek sektora publicznego. Inną kwestią jest sytuacja, kiedy korzyść za taką czynność jest pozorna. Ma ona miejsce, jeżeli świadczenie podmiotu publicznoprawnego wynika z obowiązku nałożonego przez państwo lub jednostkę samorządu terytorialnego, a nie z potrzeb podmiotu dokonującego opłaty. Tak więc brak powiązania pomiędzy opłatą i świadczeniem wzajemnym powoduje, iż jest to podatek, nawet gdy co innego wynika z jego nazewnictwa ${ }^{35}$. Analizując ekwiwalentność świadczeń, należy brać pod uwagę przede wszystkim kryteria gospodarcze, które pozwalają dokonać obiektywnej oceny. Spojrzenie subiektywne powinno się stosować w ograniczonym zakresie i tylko, jeżeli dysproporcja wartości między świadczeniami nie jest rażąca ${ }^{36}$. Ekwiwalent winien być ustalony w sposób przekonujący. Dzieje się tak w sytuacji, kiedy opiera się on na ekonomicznej kalkulacji i racjonalnie uzasadnia wysokość opłaty $^{37}$.

W doktrynie można się spotkać z próbami konkretyzacji sytuacji, w jakich dozwolone jest nałożenie opłaty na podmiot bierny tego stosunku publicznoprawnego. Zgodnie z tym możliwość obciążenia go takim świadczeniem występuje, kiedy korzysta on z urządzeń i obiektów publicznych, otrzymuje od państwa lub jednostki samorządu terytorialnego określony przywilej, a także jeżeli załatwiane są jego indywidualne sprawy. Ukazuje to jednocześnie, do czego może być zobowiązany podmiot czynny opłaty w zamian za jej uiszczenie. Dodatkowo, ze względu na związek przyczynowy łączący tę daninę publiczną i wzajemne świadczenie administracji publicznej oraz charakterystyczną cechę ekwiwalentności, obywatele w takiej samej sytuacji faktycznej winni być traktowani jednakowo ${ }^{38}$. Oznacza to, że wysokość opłaty wynikać powinna z wartości świadczenia wzajemnego, a nie z sytu-

32 Wyrok WSA w Warszawie z 14 marca 2017 r., IV SA/Wa 2825/16, LEX nr 2391813.

33 Wyrok TK z 28 czerwca 2016 r., SK 31/14, LEX nr 2067764.

34 Brzezicki, T., Opłata administracyjna. Konstrukcja prawna. Toruń 2019, s. 30-33.

35 Gliniecka, J., op. cit., s. 13-16.

36 Wyrok SA w Łodzi z 9 kwietnia 2015 r., I ACa 1475/14, LEX nr 1680045.

37 Wyrok NSA z 3 kwietnia 2012 r., I OSK 2315/11, LEX nr 1264709.

38 Wyrok WSA w Gliwicach z 15 stycznia 2013 r., IV SA/Gl 398/12, LEX nr 1296375. 
acji indywidualnej płacącego ją podmiotu. W związku z tym obywatele, którzy otrzymują to samo świadczenie publiczne, nie mogą ponosić różnych kosztów z tego tytułu poprzez zastosowanie na przykład kryterium dochodowego ${ }^{39}$. Tak samo opłata nie powinna mieć postaci zryczałtowanej, lecz odpowiadać indywidualnej wartości świadczenia ${ }^{40}$.

Wzajemność świadczeń powoduje, że między opłatą a daną czynnością urzędową podmiotu publicznoprawnego występuje bezpośredni związek ${ }^{41}$. To właśnie analiza tej wzajemności i ekwiwalentności pozwala zakwalifikować określoną daninę publiczną jako odpłatną lub nieodpłatną, a w konsekwencji odróżnić opłatę od podatku ${ }^{42}$. Brak świadczenia wzajemnego ze strony podmiotu czynnego opłaty bądź sztuczny charakter takiej czynności powoduje, że opłata może być w sensie materialnym podatkiem. Służy to ustawodawcy do ukrycia rzeczywistego charakteru prawnego zobowiązania podatkowego ${ }^{43}$.

\section{Rzeczywisty charakter prawny danin publicznych w Polsce}

Pomimo że prawu finansowemu znane jest kryterium rozróżnienia podatku od opłaty, to zakwalifikowanie ich do odpowiedniej grupy niejednokrotnie powoduje wątpliwości. Pod względem formalnym aktualnie w Polsce obowiązuje 14 różnych podatków oraz znacznie więcej opłat. Nie w każdym przypadku jednak materialny charakter daniny publicznej odpowiada zastosowanemu przez ustawodawcę nazewnictwu. Wątpliwości nie ma w klasyfikacji podatków, gdyż zapłata każdego z nich nie daje podmiotowi płacącemu możliwości domagania się spełnienia świadczenia wzajemnego. W przeciwieństwie do nich opłaty nastręczają więcej problemów w kontekście przydzielenia ich do właściwej grupy danin publicznych. Przyczyną tego mogą być kwestie techniczno-legislacyjne albo tradycyjne nazewnictwo niektórych świadczeń. Głównej pobudki takiego stanu rzeczy należy jednak upatrywać w tworzeniu przez ustawodawcę pozoru liczby obowiązujących obciążeń podatkowych. To natomiast spowodowane jest niechęcią społeczeństwa do nakładania podatków, które w powszechnej opinii są uciążliwsze niż opłaty ${ }^{44}$.

Takim przykładem jest opłata targowa. Po raz pierwszy do polskiego systemu prawnego została ona wprowadzona w 1951 r., w obecnie znanym kształcie występuje jednak od 1991 r. $^{45}$ Pobiera się ją od podmiotów dokonujących sprzedaży na targowiskach ${ }^{46}$. Sam ustawodawca podkreśla, że opłata ta oderwana jest od należności wskazanych w odrębnych

39 Wyrok NSA z 11 października 2013 r., I OSK 1673/13, LEX nr 1668022.

40 Wyrok WSA w Warszawie z 3 lipca 2013 r., VIII SA/Wa 353/13, LEX nr 1352809.

41 Wyrok NSA z 20 marca 2019 r., I GSK 3446/18, LEX nr 2676008.

42 Krzywoń, A., op. cit., s. 54-56.

43 Gomułowicz, A., Podatek a opłata, w Gomułowicz, A. i Małecki, J. (red.), Podatki i prawo podatkowe. Warszawa 2010, s. 147.

44 Dowgier, R. et al., op. cit., s. 24-25.

45 Hanusz, A., Opłata targowa, w Hanusz, A. (red.), Źródła finansowania samorządu terytorialnego. Warszawa 2015, s. 244.

46 Wyrok WSA w Gliwicach z 29 marca 2019 r. III SA/Gl 81/19, Legalis nr 1914425. 
przepisach za użytkowanie urządzeń targowych oraz za inne usługi świadczone przez prowadzącego targowisko ${ }^{47}$. Wskazuje to na brak świadczenia wzajemnego ze strony samorządu gminnego. Opłata targowa $\mathrm{z}$ całą pewnością nie jest biletem wstępu umożliwiającym wejście na teren targowiska ${ }^{48}$. Za świadczenie jednostki samorządu terytorialnego nie można uznać również możliwości prowadzenia sprzedaży na targowisku i używania urządzeń targowych, gdyż prowadzenie targowiska gminnego jest usługą komunalną, mającą charakter użyteczności publicznej ${ }^{49}$. Zatem wobec braku cechy odpłatności w opłacie targowej należy uznać ją za podatek.

Innymi opłatami wzbudzającymi wątpliwości co do ich klasyfikacji są opłaty za korzystanie ze środowiska. Zostały one uregulowane w obecnym kształcie w $2001 \mathrm{r}^{50}$ Uiszcza się je na rachunek właściwego urzędu marszałkowskiego. Zobowiązanymi do ich zapłaty są podmioty korzystające ze środowiska, które we własnym zakresie powinny ustalić ich wysokość ${ }^{51}$. Jak zauważa się w doktrynie, ta danina publiczna nie ma cechy odpłatności. Za świadczenie wzajemne z pewnością nie można uznać możliwości ubiegania się o pomoc finansową na inwestycje proekologiczne, ponieważ szanse na nią mają również podmioty niewnoszące takiej opłaty. Podmiot bierny tego świadczenia nie może żądać niczego od podmiotu czynnego ${ }^{52}$. Za ekwiwalent nie można uznać też zgody na produkcję zanieczyszczeń, gdyż państwo nie wytworzyło środowiska, a jedynie próbuje racjonalnie nim zarządzać. Świadczenie to jest nieodpłatne, albowiem zapłata go nie rodzi po stronie podmiotu publicznego wymiernego i konkretnego świadczenia ekwiwalentnego ${ }^{53}$. Wobec tego opłaty za korzystanie ze środowiska wykazują wszystkie cechy właściwe dla świadczeń podatkowych ${ }^{54}$.

Opłaty miejscowe i uzdrowiskowe są kolejnymi daninami, co do których klasyfikacji zachodzą uzasadnione wątpliwości. Do polskiego systemu prawnego zostały wprowadzone odpowiednio w $1985^{55}$ i 2005 r. ${ }^{56}$ Ich łączne omówienie uzasadnia podobny przedmiot tych świadczeń, którym jest przebywanie w danej miejscowości. W przypadku opłaty miejscowej obowiązek zapłaty powstaje w razie przebywania na określonym terenie przez czas dłuższy niż doba w celach szkoleniowych, turystycznych lub wypoczynkowych. Opłatę

47 Ustawa z dnia 12 stycznia 1991 r. o podatkach i opłatach lokalnych, tekst jedn. Dz.U. 2019 poz. 1170 z późn. zm. (dalej: piol), art. 15.

48 Wyrok NSA z 3 czerwca 1992 r., III SA 1009/92, LEX nr 23169.

49 Rozstrzygnięcie nadzorcze Wojewody Wielkopolskiego z dnia 15 maja 2009 r., NK.I-7.0911-180/09, Dziennik Urzędowy Województwa Wielkopolskiego z 2009 r. nr 114, poz. 1862.

50 Draniewicz, B., Problem konstytucyjności opłat za korzystanie ze środowiska, Państwo i Prawo 2007, nr 7, s. 70.

51 Ustawa z dnia 27 kwietnia 2001 r. - Prawo ochrony środowiska, tekst jedn. Dz.U. 2020 poz. 1219 z późn. zm., art. 284.

52 Draniewicz, B., op. cit., s. 77-78.

53 Wyrok NSA z 26 maja 2009 r., II OSK 800/08, LEX nr 574681.

54 Fill, W., Konstrukcja opłat ekologicznych w Polsce, w Liszewski, G. (red.), Opłaty samorządowe w Polsce - problemy praktyczne. Białystok 2010, s. 89-91.

55 Szczęśniak, P., Opłata miejscowa, w Hanusz, A. (red.), Źródła finansowania samorządu terytorialnego. Warszawa 2015, s. 259.

56 Kwaśniewski, R. i Majewska, I., Opłata miejscowa i uzdrowiskowa na przykładzie gmin województwa kujawsko-pomorskiego, Prawo Budżetowe Państwa i Samorządu 2016, nr 4, s. 103. 
uzdrowiskową pobiera się w takich samych warunkach, a także w sytuacji pobytu o zamiarze zdrowotnym ${ }^{57}$. Nazewnictwo tych danin publicznych wskazuje, że za ich spełnienie przysługuje osobie fizycznej świadczenie wzajemne państwa bądź jednostki samorządu terytorialnego. W rzeczywistości jednak podmioty zobowiązane do uiszczenia tej opłaty wszelkie swoje cele realizują w ramach czynności cywilnych. W zamian za zapłatę korzystają z usług dostępnych na rynku. Obecność podmiotu publicznego jest tutaj całkowicie zbędna, gdyż w zamian za opłatę nie spełnia żadnych potrzeb obywatela. W związku z tym należy stwierdzić, że w opłatach tych nie występuje świadczenie wzajemne państwa ani jednostki samorządu terytorialnego, co oznacza brak ekwiwalentności i odpłatności tych danin publicznych ${ }^{58}$. Dlatego mają one charakter podatkowy i na gruncie materialnym należy uznać je za podatki.

Następną niewłaściwie zakwalifikowaną daniną publiczną jest opłata od posiadania psów. Gmina, jako jednostka samorządu terytorialnego, może pobrać ją od osoby fizycznej za sam fakt bycia dysponentem tego zwierzęcia ${ }^{59}$. Do końca 2006 r. świadczenie to nosiło jeszcze nazwę podatku ${ }^{60}$. Decyzja ustawodawcy o zmianie jego nazewnictwa wydaje się błędna, gdyż ze strony samorządu gminnego nie występuje tu żadne świadczenie wzajemne. Opłata należna jest za sam fakt posiadania psa, które nie jest uzależnione od samorządu gminnego. Poprzez brak cechy odpłatności świadczenie to na gruncie materialnym należy określić więc jako podatek.

Ostatnią z obowiązujących opłat, którą warto przybliżyć na gruncie tych rozważań, a wykazującą cechy podatku, jest opłata reklamowa. Poszerzyła ona katalog danin publicznych w 2015 r. ${ }^{61}$ Zobowiązanymi do jej zapłaty są właściciele, użytkownicy i posiadacze samoistni nieruchomości, na których znajdują się tablice lub urządzenia reklamowe, niezależnie od tego, czy są na nich eksponowane konkretne treści reklamowe ${ }^{62}$. Opłata reklamowa, oprócz funkcji fiskalnej, odgrywa głównie rolę regulacyjną poprzez wpływ na politykę przestrzenną i zachowanie ładu przestrzennego. Nie można jednak uznać, że uchwała gminy dotycząca małej architektury jest świadczeniem wzajemnym. Wprawdzie podmiot bierny opłaty może czerpać korzyści z poprawy ładu przestrzennego, nie sposób jednak uznać, że jest to świadczenie indywidualne w zamian za zapłatę. Nie występuje relacja między samorządem gminnym a obywatelem, co jest konsekwencją, że akt prawa miejscowego nie

57 Art. 17 piol.

58 Burzec, M., Opłata miejscowa jako danina nakładana na turystów, Samorząd Terytorialny 2019, nr 6, s. 90.

59 Art. 18a piol.

60 Korczak, J., Opłaty lokalne jako rodzaj daniny publicznej, w Korczak, J. et al., Opłaty w prawie administracyjnym. Wrocław 2013, s. 285.

61 Antonów, D., Charakter prawny opłaty reklamowej, Finanse Komunalne 2017, nr 1-2, s. 115.

62 Art. 17a piol. 
zapewnia ekwiwalentu za uiszczoną opłatę ${ }^{63}$. W związku z tym opłatę reklamową należy traktować jak podatek ${ }^{64}$.

Wskazane opłaty, które na gruncie materialnym są w rzeczywistości podatkami, powinny nasunąć refleksję o potrzebie naprawy polskiej systematyki danin publicznych. Wydaje się jednak, że obrany przez ustawodawcę kierunek jest przeciwny. Od początku 2021 r. w Polsce zaczęła obowiązywać opłata od środków spożywczych, której podlegają wprowadzane na rynek krajowy napoje z dodatkiem cukrów, substancji słodzących, tauryny oraz kofeiny ${ }^{65}$. Podmiotami zobowiązanymi do jej uiszczenia są osoby fizyczne, osoby prawne i jednostki organizacyjne nieposiadające osobowości prawnej dokonujące wprowadzenia tych produktów do obrotu ${ }^{66}$. W samym akcie normatywnym ustanawiającym tę daninę publiczną nie wskazano żadnego świadczenia wzajemnego w związku z jej uiszczeniem. Wobec braku jakiegokolwiek ekwiwalentu dla podmiotu biernego należy stwierdzić brak cechy odpłatności we wskazanej opłacie. Nie można też uznać, że świadczeniem wzajemnym w tym przypadku jest samo dopuszczenie tych produktów do obrotu na wzór zezwolenia czy koncesji. Zgodnie z ustawą ustanawiającą tę opłatę należna jest ona za samo wprowadzenie produktów na rynek, nie wymaga uzyskania zgody organu publicznego do podejmowania takich czynności. Prawo nie reglamentuje tego typu działalności. Dlatego danina ta bardziej przypomina podatek od towarów i usług niż opłatę administracyjną za udzielenie zezwolenia. Również w uzasadnieniu do projektu ustawy wprowadzającej opłatę od środków spożywczych nie ma żadnego wskazania świadczenia wzajemnego podmiotu publicznego. Jest on poświęcony głównie celom społecznym i zdrowotnym takiego rozwiązania ${ }^{67}$. Ponieważ więc nie ma ekwiwalentu za uiszczoną opłatę, a także możliwości dochodzenia przez podmiot bierny opłaty jakiegokolwiek indywidualnego świadczenia wzajemnego względem państwa lub jednostki samorządu terytorialnego należy stwierdzić całkowity brak odpłatności omawianej daniny publicznej. W konsekwencji opłata od środków spożywczych, pomimo nazwy wprowadzającej w błąd, jest w rzeczywistości nowym podatkiem.

\section{Podsumowanie}

W celu spełnienia obowiązku ponoszenia ciężarów i świadczeń publicznych trzeba płacić wiele danin publicznych. Znajdują się one w centrum uwagi prawa finansowego poprzez swój udział w ogólnych dochodach państwa. Wśród nich zdecydowanie największe znacze-

63 Liszewski, G., Opłata reklamowa jako przykład złej legislacji podatkowej, w Piszcz, A. et al. (red.), Państwo. Gospodarka. Prawo. Ksiega dedykowana Profesorowi Cezaremu Kosikowskiemu z okazji jubileuszu pracy naukowej na Wydziale Prawa Uniwersytetu w Białymstoku. Białystok 2015, s. 402.

64 Hadel, M., Opłata reklamowa jako instrument kształtowania gminnej polityki przestrzennej, Finanse Komunalne 2016, nr 7-8, s. 79-83.

65 Ustawa z dnia 11 września 2015 r. o zdrowiu publicznym, tekst jedn. Dz.U. 2021 poz. 183 z późn. zm. (dalej: zp), art. 12a.

66 Art. $12 \mathrm{~d}$ zp.

67 Uzasadnienie do ustawy z dnia 14 lutego 2020 r. o zmianie niektórych ustaw w związku z promocją prozdrowotnych wyborów konsumentów (Druk Sejmowy nr 210, Sejm IX Kadencji). 
nie mają podatki, co może prowadzić do utożsamienia ich ze wszystkimi świadczeniami publicznymi. Zgodnie z zaprezentowaną analizą w doktrynie został wskazany jasny podział danin publicznych, który pozwala odróżnić podatek od opłaty.

Świadczenia te, pomimo znacznego podobieństwa, różnią się odpłatnością. Podatek nie ma cechy odpłatności, w związku z czym podmiot bierny nie może żądać żadnego świadczenia wzajemnego za zapłatę. Opłata natomiast jest odpłatna, co oznacza, że za jej uiszczenie przysługuje ekwiwalent ze strony państwa lub jednostki samorządu terytorialnego. Odpłatność powinna charakteryzować się przede wszystkim odpowiednim stopniem ekwiwalentności, czyli wartość jednego świadczenia winna odpowiadać wartości drugiego świadczenia. Pomiędzy nimi powinna być bezpośrednia i indywidualna więź.

Analiza obowiązujących w Polsce danin publicznych obrazuje tendencję ustawodawcy do sztucznego zwiększania liczby opłat. Objawia się to poprzez nazywanie świadczeń publicznych opłatami, pomimo występujących w nich wyraźnych cech podatkowych. Taki stan rzeczy można stwierdzić wśród ugruntowanych już w polskim systemie prawnym opłat: targowej, za korzystanie ze środowiska, miejscowej, uzdrowiskowej, od posiadania psów oraz reklamowej. Liczba takich świadczeń zwiększała się sukcesywnie w ciągu lat. Oprócz tego można zauważyć, że tendencja ta nie zmienia się, gdyż na początku 2021 r. weszła w życie nowa opłata od środków spożywczych. Również w niej cecha odpłatności nie występuje, co sprawia, że na gruncie materialnym są to podatki. Nakładając takie świadczenia publiczne, ustawodawca wprowadza w błąd co do ogólnej liczby obowiązujących podatków oraz charakteru prawnego poszczególnych danin publicznych. Ma to bezpośrednie przełożenie na sferę uprawnień obywatela, który przecież powinien otrzymać indywidualne świadczenie wzajemne za uiszczoną opłatę. $Z$ jednej strony uzasadnienia takiego działania ustawodawcy należy szukać wśród podejścia społeczeństwa do obciążeń podatkowych. Z drugiej zaś mała świadomość społeczna na temat charakteru prawnego danin publicznych w Polsce może wynikać z dominacji udziałów obciążeń podatkowych w dochodach państwa. Nie zmienia to faktu, że świadczenia publiczne nazwane przez ustawodawcę opłatami, które nie mają cechy odpłatności, są w rzeczywistości zakamuflowanymi podatkami.

\section{Bibliografia}

\section{Literatura}

Adam, L. i Mazurkiewicz M., Opłaty, w Weralski, M. (red.), System instytucji prawno-finansowych $P R L$, t. 3. Wrocław 1982.

Antonów, D., Charakter prawny opłaty reklamowej, Finanse Komunalne 2017, nr 1-2.

Bożek, W., Znaczenie danin publicznych w budżecie państwa, w Mańczyk, P. (red.), Daniny publiczne $w$ Polsce i innych państwach Europy. Szczecin 2018.

Brzezicki, T., Opłata administracyjna. Konstrukcja prawna. Torun 2019.

Burzec, M., Opłata miejscowa jako danina nakładana na turystów, Samorząd Terytorialny 2019, nr 6. Dębowska-Romanowska, T., Prawo daninowe - podstawowe pojęcia konstytucyjne i ustawowe cz. I, Glosa 1996, nr 11.

Dowgier, R. et al., Podatki i opłaty lokalne. Komentarz. Warszawa 2020. 
Draniewicz, B., Problem konstytucyjności opłat za korzystanie ze środowiska, Państwo i prawo 2007, nr 7.

Fill, W., Konstrukcja opłat ekologicznych w Polsce, w Liszewski, G. (red.), Opłaty samorzadowe w Polsce - problemy praktyczne. Białystok 2010.

Florczak-Wątor, M., Obowiązek ponoszenia ciężarów i świadczeń publicznych, w Tuleja, P. (red.), Konstytucja Rzeczypospolitej Polskiej. Komentarz. Warszawa 2019.

Gliniecka, J., Opłaty publiczne w Polsce. Analiza prawna i funkcjonalna. Bydgoszcz-Gdańsk 2007.

Gomułowicz, A., Podatek a opłata, w Gomułowicz, A. i Małecki, J. (red.), Podatki i prawo podatkowe. Warszawa, 2010.

Hadel, M., Opłata reklamowa jako instrument kształtowania gminnej polityki przestrzennej, Finanse Komunalne 2016, nr 7-8.

Hanusz, A., Opłata targowa, w Hanusz, A. (red.), Źródła finansowania samorządu terytorialnego. Warszawa 2015.

Korczak, J., Opłaty lokalne jako rodzaj daniny publicznej, w Korczak et al., Opłaty w prawie administracyjnym. Wrocław 2013.

Kotlińska, J., Dochody własne jednostek samorządu terytorialnego w Polsce, Ruch Prawniczy, Ekonomiczny i Socjologiczny 2009, nr 3.

Krzywoń, A., Podatki i inne daniny publiczne - podstawowe pojęcia konstytucyjne, Zeszyty Naukowe Sądownictwa Administracyjnego 2011, nr 2.

Kwaśniewski, R. i Majewska, I., Opłata miejscowa i uzdrowiskowa na przykładzie gmin województwa kujawsko-pomorskiego, Prawo Budżetowe Państwa i Samorządu 2016, nr 4.

Liszewski, G., Opłata reklamowa jako przykład złej legislacji podatkowej, w Piszcz, A. et al. (red.), Państwo. Gospodarka. Prawo. Księga dedykowana Profesorowi Cezaremu Kosikowskiemu z okazji jubileuszu pracy naukowej na Wydziale Prawa Uniwersytetu w Białymstoku. Białystok 2015.

Mirek, I., Daniny publiczne w prawie niemieckim. Warszawa 1999.

Münnich, M., Charakterystyka opłaty legalizacyjnej jako daniny publicznej, Przegląd Prawa Publicznego 2015, nr 10.

Niesiobędzka, M., Relacje podatnik-państwo jako predyktory moralności podatkowej, Psychologia Społeczna 2009, t. 4.

Popławski, M., Normatywne pojęcie podatku, w Etel, L. (red.), Ordynacja podatkowa. Komentarz. Warszawa 2017.

Szczęśniak, P., Opłata miejscowa, w Hanusz, A. (red.), Źródła finansowania samorządu terytorialnego. Warszawa 2015.

Węgrzynowski, Ł., Ekwiwalentność świadczeń w umowie wzajemnej. Warszawa 2011.

Wójtowicz, W., Podstawowe zagadnienia ustawy o finansach publicznych, w Wójtowicz, W. (red.), Zarys finansów publicznych i prawa finansowego. Warszawa 2020.

\section{Akty prawne}

Konstytucja Rzeczypospolitej Polskiej z dnia 2 kwietnia 1997 r. (Dz.U. 1997 nr 78 poz. 483 z późn. $z m$.).

Ustawa z dnia 12 stycznia 1991 r. o podatkach i opłatach lokalnych (tekst jedn. Dz.U. 2019 poz. 1170 z późn. $z m$.$) .$

Ustawa z dnia 29 sierpnia 1997 r. Ordynacja podatkowa (tekst jedn. Dz.U. z 2020 poz. 1325 z późn. zm.).

Ustawa z dnia 27 kwietnia 2001 r. - Prawo ochrony środowiska (tekst jedn. Dz.U. 2020 poz. 1219 z późn. $z m$.). 
Ustawa z dnia 27 sierpnia 2009 r. o finansach publicznych (tekst jedn. Dz.U. z 2019 poz. 869 z późn. zm.).

Ustawa z dnia 11 września 2015 r. o zdrowiu publicznym (tekst jedn. Dz.U. 2021 poz. 183 z późn. zm.).

Uzasadnienie do ustawy z dnia 14 lutego 2020 r. o zmianie niektórych ustaw w związku z promocją prozdrowotnych wyborów konsumentów (Druk Sejmowy nr 210, Sejm IX Kadencji).

\section{Orzecznictwo}

Rozstrzygnięcie nadzorcze Wojewody Wielkopolskiego z dnia 15 maja 2009 r., NK.I-7.0911-180/09

(Dziennik Urzędowy Województwa Wielkopolskiego z 2009 r. nr 114, poz. 1862).

Wyrok NSA z 3 czerwca 1992 r., III SA 1009/92, LEX nr 23169.

Wyrok NSA z 28 października 2008 r., II OSK 1179/07, LEX nr 1012219.

Wyrok NSA z 26 maja 2009 r., II OSK 800/08, LEX nr 574681.

Wyrok NSA z 3 kwietnia 2012 r., I OSK 2315/11, LEX nr 1264709.

Wyrok NSA z 26 lipca 2012 r., I OSK 679/12, LEX nr 1392334.

Wyrok NSA z 11 października 2013 r., I OSK 1673/13, LEX nr 1668022.

Wyrok NSA z 20 marca 2019 r., I GSK 3446/18, LEX nr 2676008.

Wyrok NSA z 22 listopada 2019 r., II GSK 991/19, LEX nr 2764702.

Wyrok SA w Łodzi z 9 kwietnia 2015 r., I ACa 1475/14, LEX nr 1680045.

Wyrok TK z 17 stycznia 2006 r., U 6/04, OTK 2006, nr 1, poz. 3.

Wyrok TK z 28 czerwca 2016 r., SK 31/14, LEX nr 2067764.

Wyrok WSA w Gliwicach z 15 stycznia 2013 r., IV SA/Gl 398/12, LEX nr 1296375.

Wyrok WSA w Gliwicach z 29 marca 2019 r., III SA/Gl 81/19, Legalis nr 1914425.

Wyrok WSA w Poznaniu z 18 grudnia 2019 r., III SA/Po 371/19, LEX nr 2761074.

Wyrok WSA w Warszawie z 3 lipca 2013 r., VIII SA/Wa 353/13, LEX nr 1352809.

Wyrok WSA w Warszawie z 14 marca 2017 r., IV SA/Wa 2825/16, LEX nr 2391813.

\section{Strony internetowe}

Projekt ustawy - Ordynacja podatkowa z dnia 6 października 2017 r. https://mf-arch2.mf.gov.pl/ ministerstwo-finansow/dzialalnosc/ciala-kolegialne/komisja-kodyfikacyjna-ogolnego-prawa-podatkowego/prace-komisji, dostęp 31.03.2021.

Rada Ministrów, Sprawozdanie z wykonania budżetu państwa za okres od 1 stycznia do 31 grudnia 2018 r., tom I, 2019. https://www.gov.pl/web/finanse/sprawozdanie-roczne-za-2018, dostęp 12.11.2020.

Rada Ministrów, Sprawozdanie z wykonania budżetu państwa za okres od 1 stycznia do 31 grudnia 2019 r., tom I, 2020. https://www.gov.pl/web/finanse/sprawozdanie-roczne-za-2019-rok, dostęp 12.11.2020 